\title{
The Effectiveness of $\mathcal{A}$ developed Curriculum of Food
}

Quality Control in The Light of Scientific Standards in Developing The practices of Food Quality

Control And Safety in Hotels for Students of Technical Secondary Hotel School

Ashraf Fathy Rabie

PHD Study College of Education

Minia University

\section{Abstract}

he present study aims at investigating the effectiveness
of a developed curriculum of food quality control in the
light of scientific standards in developing the practices of food quality control and safety in hotels for students of technical secondary hotel schools. To achieve the objectives of the study, the researcher adopted one group quasi- experimental design. The study sample represents the experimental group who had pre-scale before the implementation of the program. The suggested curriculum was taught, and then a post- scale was applied to see how students are improved. Participants of the study were 22 female students of technical secondary hotel school in Minia enrolled in the first semester of the academic year 2019-2020. The study findings revealed that there were significant differences (0.01) (favoring the post-performance). Findings also revealed that the suggested curriculum has a large effect on students' achievement. Based on the above findings, the researcher recommended that developing curricula of technical education should include food safety topics and those curricula should be developed according to the market needs

Key words: Food quality control, scientific standards, quality control and food safety practices

\section{Introduction:}

Food quality and safety gets a great attention as a result of the increased awareness of nutrition fields. The past two decades witnessed a huge development in the field of food producing, keeping and circulation that led to the spread of food related diseases caused by wrongly food circulation. Having a safe and good quality food is considered an important element to improve the human health, prevent diseases, and improve the human lifestyle. Food and health have mutual relationship because 
everyone needs safe and healthy food to be in a good health. The better food is, the better our lives will be. Gibney, et al. (2013)

Food safety and quality are considered a comprehensive philosophy that represents the backbone of the hotel establishments to continue, so the establishments have a direct responsibility to ensure the quality and safety of food they present to save the health of their clients and meet their desires and expectations in getting a healthy and safe food.

Observing of food production in hotels and restaurants is a big responsibility held by those people who have a good awareness in food circulation and those who have a good knowledge of heath affairs, and food safety and quality. Keeping food quality should be everyone's goal who works in food preparation and circulation. The technical control of food quality is made by in charge persons or departments whose mission is to check the hotel income raw materials to know its quality and validity and also to put different specifications to the produced food and to find different ways to measure the production quality from its ingredients and features. The measurement should start from the raw materials until the final production. (Al-Dabbas, 2003)

\section{Statement of the problem}

The students of Food production department complain of ambiguity of some parts of food quality control curriculum confirming that some topics are not related to each other. Moreover, difficulty in understanding some terms in a correct way and the curriculum does not show the control practices of quality and safety in hotels. To solve this problem, so the present study investigates the effectiveness of a developed curriculum of food quality control in the light of scientific standards in developing the practices of food quality control and safety in hotels for students of technical secondary hotel schools.

\section{Theoretical background and previous literature}

Developing the curricula of food quality control in the light of scientific standards for developing the practices of food quality control and safety is an urgent necessity to help work and production institutions compete and follow quality standards with its all demands thus technical education and the professional training are and should be one of the most important governmental concerns. Nowadays the technical education is one of the strategic sectors that get a special 
attention to raise it up and qualify a technical graduate with a scientific, cultural and moral base to qualify him to follow the development in his field, upgrade his social level and follow his study and training. This graduate should have high skills that match the national standards and allows him to join the labor market directly and adapt quickly with market needs. National Authority for Quality Assurance and Accreditation (2010)

Many researches and studies affirmed the importance of developing the academic curricula according to national and international quality standards, Hassan (2010), Abd El-Qader (2015), Mohammad (2016) and Mohammad (2017). Other studies, that paid attention to the technical hotel education, have recommended developing the academic curricula and professional training and revising the curricula in the light of the scientific standards such as El-Badry (1998), Badr (2003) \& Hassanein (2007).

The important role of food production quality control does not stop on a specific producing process, in a specific machine or with a worker but it includes them all. Whereas the quality control starts on receiving the raw materials and assures that they match their standard specifications, follows how accurate the machine and tools are, how efficient the production process is, the efficiency of workers and the range of matching the final products to their own specifications thus they should have a unified quality (Youssef, 2003 pp49).

Quality control pays attention to observing the final production to clear it up from any faults to assure it satisfy the client needs, has changed. Finding any faults after the production is no longer accepted logically. It became necessary to depend on the way of preventing the faults pre and while the production process and taking protective procedures that ensure achieving the demanded quality level. These procedures are done to all production stages from its design to its usage. This way can decrease the faults, cost and increase the productivity (Qenawi, 2008 pp. 49).

\section{Commentary}

The results of many study confirmed the human role and his preparation level so this present study is a try to treat the faults of the effective human preparation stage in guesting field according to the results of the aforementioned studies and what they recommended. Moreover, this study is a step to prepare a worker who can achieve the food quality and safety for the 
clients of hotel and tourism establishments by preparing a developed curriculum to manage food quality and safety. It was necessary to prepare hotel school students to be aware of the principles and practices of food and drinks quality and safety control in hotels, to meet marketing needs and also to improve the level of guesting establishment quality. Therefore, this study recommends the importance of applying overwhelming quality system on hotels labor and there have to be instructions for them and to be sure that all the procedures are going well.

\section{Methodology}

Participants of the study consisted of 22 students in G4 (Food production deparment) who are in Minia Technical Secondary Hotel School in the academic year 2019/2020 and they represent the experimental group. The researcher conducted a list of the suggested standards for food quality control curriculum for the hotel technical students by which the current curriculum can be improved. This list included two main fields: food quality field and food safety field. Moreover, the researcher conducted a form to analyze the curriculum content in the light of the suggested standards to know if the current curriculum match these standards or not. As a result, the current curriculum did not meet $80 \%$ of the suggested standards, so it was improved in the light of suggested standards therefore the researcher prepared a suggested curriculum of food quality control for hotel technical students. The suggested curriculum included a student book and a teacher's guide. The researcher made sure of the validity of the student book and the teacher's guide by consulting a group of specialists of professors to assure that they suit the usage way then the researcher prepared a scale of food quality and safety control practices that consists of 65 items shared on 9 axes. To ensure validity of the scale, it was submitted to specialized jury members in the field of nutrition and experts in food quality and safety control sciences in tourism and to hotels. The jury members were asked to comment on suitability of the scale's items to achieve the study objectives, clarity of the scale items and clarity of the scale instructions. The scale was modified according to the jury members' comments and suggestions. The reliability coefficient of the agent axes was measured using Cronbach's alpha and it was between (0.672 0.844) which is statistically accepted.

The researcher adopted one group quasi-experimental design. After Applying the tools on the sample of the study and 
computing the results implementing the experiment according to the teacher's guide on the experimental group the data were collected and computed by using (SPSS) Statistical Package for Social Sciences

\section{Results}

\section{Hypothesis One:}

There is a statistically significant difference (favoring the postperformance) between mean scores obtained by the experimental group on the post scale of food quality

control and safety practices. In order to verify the validity of this hypothesis, t- test was used to compare the mean scores of the pre-post performances. The results of the $t$ - test proved to be statistically consistent with the hypothesis. The results are shown in the following table:

Table (1): $t$ - test results of mean scores obtained by the experimental group on the pre-post performance on Food quality Control And Safety practices scale

\begin{tabular}{|c|c|c|c|c|c|c|c|}
\hline Items & Marks & Measurement & Average & S D & $\begin{array}{l}\text { t- } \\
\text { value }\end{array}$ & Sig. & $\begin{array}{l}\text { Sign } \\
\text { type }\end{array}$ \\
\hline \multirow{2}{*}{$\begin{array}{l}\text { 1- Good practices in } \\
\text { purchasing stage }\end{array}$} & 35 & Pre-performance & 25.7 & 4.2176 & \multirow{2}{*}{5.626} & \multirow{2}{*}{0.01} & \multirow{2}{*}{ Sign } \\
\hline & 35 & Post-performance & 33.7 & 1.7029 & & & \\
\hline \multirow{2}{*}{$\begin{array}{l}\text { 2- Good practices in } \\
\text { receiving stage }\end{array}$} & 35 & Pre- performance & 26 & 5.2068 & \multirow{2}{*}{3.989} & \multirow{2}{*}{0.01} & \multirow{2}{*}{ Sign } \\
\hline & 35 & Post-performance & 32.8 & 1.3984 & & & \\
\hline \multirow{2}{*}{$\begin{array}{l}\text { 3- Good practices in Storage } \\
\text { and reissue operations from } \\
\text { stores }\end{array}$} & 40 & Pre-performance & 28 & 4 & \multirow[b]{2}{*}{7.282} & \multirow[b]{2}{*}{0.01} & \multirow[b]{2}{*}{ Sign } \\
\hline & 40 & Post-performance & 37.6 & 1.7763 & & & \\
\hline \multirow{2}{*}{$\begin{array}{l}\text { 4- Good practices during the } \\
\text { pre-cooking stage }\end{array}$} & 40 & Pre- performance & 33.1 & 10.948 & \multirow{2}{*}{0.960} & \multirow{2}{*}{$\begin{array}{l}0.36 \\
2 \\
\end{array}$} & \multirow{2}{*}{ Non } \\
\hline & 40 & Post-performance & 36.1 & 1.8529 & & & \\
\hline \multirow{2}{*}{$\begin{array}{l}\text { 5- Good practices in cooking } \\
\text { and keeping }\end{array}$} & 35 & Pre-performance & 25.6 & 3.8930 & \multirow{2}{*}{4.556} & \multirow{2}{*}{0.01} & \multirow{2}{*}{ Sign } \\
\hline & 35 & Post-performance & 31.9 & 1.6633 & & & \\
\hline \multirow{2}{*}{$\begin{array}{l}\text { 6- Health requirements for } \\
\text { workers of handling food }\end{array}$} & 35 & Pre-performance & 27.8 & 4.1579 & \multirow{2}{*}{3.251} & \multirow{2}{*}{0.01} & \multirow{2}{*}{ Sign } \\
\hline & 35 & Post-performance & 32.5 & 2.2730 & & & \\
\hline \multirow{2}{*}{$\begin{array}{l}\text { 7- Good practices of places of } \\
\text { food preparation \& handling } \\
\text { in hotels }\end{array}$} & 35 & Pre- performance & 27.1 & 3.8715 & \multirow[b]{2}{*}{3.374} & \multirow[b]{2}{*}{0.01} & \multirow[b]{2}{*}{ Sign } \\
\hline & 35 & Post-performance & 32.4 & 1.6465 & & & \\
\hline \multirow{2}{*}{$\begin{array}{l}\text { 8- Health requirements for } \\
\text { dealing with equipment and } \\
\text { tools for trading and } \\
\text { preparing meals in hotels }\end{array}$} & 35 & Pre- performance & 26.7 & 3.8887 & \multirow[b]{2}{*}{4.268} & \multirow[b]{2}{*}{0.01} & \multirow[b]{2}{*}{ Sign } \\
\hline & 35 & Post-performance & 33.1 & 2.4244 & & & \\
\hline \multirow{2}{*}{$\begin{array}{l}\text { 9- Good practices in garbage } \\
\text { disposal }\end{array}$} & 35 & Pre- performance & 25.7 & 5.3965 & \multirow{2}{*}{4.380} & \multirow{2}{*}{0.01} & Sign \\
\hline & 35 & Post-performance & 32.3 & 2.3118 & & & \\
\hline Quality control practices & 325 & Pre- performance & 234 & 25.05 & 7.549 & 0.01 & sign \\
\hline & & Post-performance & 302.4 & 7.26 & & & \\
\hline
\end{tabular}


As presented in the above table, it is clear that the experimental treatment of this study effectively showed an improvement in all demanded practices of the students. There is a statistically significant difference (favoring the postperformance). between mean scores obtained by the experimental group on the post scale of food quality control and safety practices in all practices except practice number (4) that is (the good practices while preparing for cooking) not a sign statistically.

The students had a previous knowledge with some sides of this practice that decreased the effect. The other practices had a big effect that inflects the effect range of the independent variable of the developed curriculum to teach food quality control in the light of the scientific standards in improving the quality control practices for hotel technical students (the study sample) with a great effect. Using a developed curriculum to teach food quality control led to improving the practices of quality control of hotel technical students (the study sample).

It shows that there is a statistically significant difference between the students' average marks in both pre - post performances to measure the quality control practices favoring the post-performance. This difference is caused by the effect of the experimental treatment of the developed curriculum in food quality control in the light of the scientific standards as an independent variable not a dependent one.

\section{Discussion, conclusion and recommendations:}

Based on the aforementioned results, the study found that the participants of the study have gained food quality and safety control practices as a result of studying food quality control developed curriculum in the light of the scientific standards. Thus, those results confirmed the effect of the developed curriculum. Moreover, the present study like other studies confirms the importance of human being in applying the practices of food quality control in hotels and those results were confirmed by, Walid Mohammed (1998), Samy (2004), Abu Qamar (2006), Mohammad (2007), Sobhy (2013), Johnston, et al. (2014) , and Pleitner, et al. (2015) and those studies recommend the importance of labor training on following the good and 
healthy processing practices in food circulation and preparation stages by giving courses about this. These courses aim to provide the kitchen labor with health standard level before they get their jobs. It is necessary to the labor with specific programs to promote the main control in dangers and food safety. Samy's study (2004) also recommends the importance of preparing qualified labor on quality practices in general and food and drinks quality and safety in particular. Whereas the main problem the hotels face to improve, the quality is the labor. In Egypt the labors are not qualified enough. The results of this study are in alignment with the results of many other studies that assure the effect of constructivist education strategy as a teaching method used in many subjects especially in science and proved its efficiency to teach science and achieve many educational goals. Some studies of those are Mosbah (2103), Akay et al. (2012), Jacqueline (2013) and Rabei (2016).

Finally, we can say that the effect of the developed curriculum of food quality control, in the light of the scientific standards in developing the practices of food quality control and safety in hotels for students of technical secondary hotel schools is considered a result for using the developed curriculum, the constructivism based strategies.

According to the aforementioned results, discussions and conclusions, this study recommends the following points:

1- Paying attention for developing the academic curricula improvement of the hotel technical education according to the market needs.

2- Creating the academic curricula according to learning strategies based on the constructivist theory for its great advantage in making students more active and increasing their desire to learn.

3- The academic curricula in all educational stages should include food safety topics.

\section{References}

- Abd El-Qader, R. M. (2015). Development of Mathematics Curriculum of Secondary Stage in the light of Suggested 
Standard Levels and its Effectiveness in the Mathematical Thinking and Decision-Making. Unpublished PHD thesis, Ain Shams University, Egypt

- Al-Dabbas, N. (2003). Food Hygiene and Safety in Hotels, Amman: Dar Al-Hamid for Publishing and Distribution

- Abu Qamar, M. S. (2006). HACCP applications to ensure the safety and quality of food services provided in hotels. Unpublished M.A. Thesis, Faculty of Tourism and Hotels, Helwan University, Egypt.

- Abu Zaid, L. S. (2001). The Effect of A Proposed Program in Food Education Using V Figure Maps on Cognitive Achievement, Manual Skills, and Food Awareness among Pre-service Kindergarten Teachers. Unpublished PHD thesis, Faculty of Education, South Valley University, Egypt.*

- Akay, S. O. \& Kaya, B and Kılıç, S. (2012).The Effects of Concept Maps on The Academic Success And Attitudes of 11th Graders While Teaching Urinary System. International online Journal of Primary Education Volume (1), issue 1.

- Badr, H. J. (2003). Developing A Tourism Economics Curriculum in Hotel Secondary Education in the Light of Contemporary Developments. Unpublished M.A. Thesis. Faculty of Education, Ain Shams University, Egypt.

- El-Badry, M. H. (1998). Developing Some Curricula of Advanced Technical Schools of Hotel Affairs and Tourism Services (The Five-year System) in The light of The Requirements of Business Community in Egypt. Unpublished PHD thesis, Faculty of Education, Menoufia University, Egypt.

- Gibney, M. J., Lanham-New, S. A., Cassidy, A., \& Vorster, H. H. (Eds.). $(Y \cdot 1 T$ ). Introduction to human nutrition. John Wiley \& Sons.

- Hassan, H. I. (2010). The Effect of A Program Based on The Standards of Teaching Arabic Language in Developing Life Skills and Thinking Skills among High School students. The scientific journal, College of Education, Assiut University. Vol. 26, No. 1, pp. 418 - 461, January 2010.

- Hassanein, E. A. (2007). The Development of Hotel Education, The five-year system As An entry Point for The Development of 
Tourism in Egypt. Unpublished PHD thesis, Faculty of Education, Mansoura University, Egypt.

- Jacqueline, V. ( 2013). The use of Concept Mapping And Vee Heuristics in Higher Education to Promote Critical Reflection And Meaningful Learning. Journal for Educators, Teachers and Trainers. Vol. 4 (1).

- Johnston, L. M., Wiedmann, M., Orta-Ramirez, A., Oliver, H. F., Nightingale, K. K., Moore, C. M., ... \& Jaykus, L. A. (2014). Identification of core competencies for an undergraduate food safety curriculum using a modified Delphi approach. Journal of Food Science Education. Vol 13(1), 12-21.

- Misbah, D. M. (2013). Effectiveness of A Constructivism -Based proposed Strategy for Teaching Science in Developing Scientific Concepts, Skills of Science Operations, and Laboratory Skills for Students of The Second Part of Basic Education in Libya. Unpublished PHD. Institute of Educational Studies, Cairo University, Egypt.

- Mohammad, G. A. (2017). Developing A Home Economics Curriculum for the Primary Stage in the Light of National Standards and Measuring its Effectiveness on Achievement and Developing Thinking Skills for Female Students and Assessing Female teachers. Unpublished PHD thesis, Faculty of Home Economics, Helwan University, Egypt.

- Mohammad, H. S. (2016). A Proposed Concept for developing a history curriculum at the secondary stage in light of quality standards and developing historical thinking skills and its direction towards it. Unpublished PHD thesis, Faculty of Education, Zagazig University, Egypt.

- Mohammad, I. A. (2007). Evaluation of Food Services Quality Provided by Nutrition Companies. Unpublished M.A. Thesis, Faculty of Tourism and Hotels, Helwan University, Egypt.

- Mohammad, W. M. (1998). Health aspects as an influencing factor in total quality management in the Food and Beverage Department. Unpublished M.A Thesis, Faculty of Tourism and Hotels, Helwan University, Egypt.

- National Authority for Quality Assurance and Accreditation (2010). Pre-University Education Institutions Document Secondary Education Stage. 
- Pleitner, A. M., Chapin, T. K., Hammons, S. R., Stelten, A. V., Nightingale, K. K., Wiedmann, M., ... \& Oliver, H. F. (2015). Development and Evaluation of a Multi-Institutional Case Studies-Based Course in Food Safety. Journal of Food Science Education, 14(3), 76-85.

- Qenawi, M. N. (2008). Food Quality and Total Quality Management. Faculty of Agriculture, Minia University, Egypt.

- Rabie, A. F. (2016). Effectiveness of A Nutritional Health Proposed Unit Based on Concept Maps in Developing Nutritional Awareness of Hotel Secondary School Students in Minia. Unpublished M.A. Thesis. Faculty of Education, Minia University, Egypt

- Sami, M. A. (2004). Evaluation of quality applications in Luxor hotels. Unpublished M.A Thesis, Faculty of Tourism and Hotels, Helwan University, Egypt.

- Sobhy, S. S. (2013). Evaluation of Health conditions in Hotel Kitchens. Unpublished PHD thesis, Faculty of Tourism and Hotels, Helwan University, Egypt.

- Youssef, M. K. (2003). Determinants of Food Quality. Alexandria: Modern Knowledge Library 